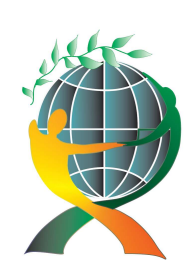

\author{
(online) $=$ ISSN $2285-3642$ \\ ISSN-L = $2285-3642$ \\ Journal of Economic Development, Environment and People \\ Volume 5, Issue 2, 2016 \\ URL: http://jedep.spiruharet.ro \\ e-mail: office jedep@spiruharet.ro
}

\title{
Premises for Adapting Curriculum and Educational Package to Labor Market Requirements
}

\author{
Luise Mladen ${ }^{1}$, Rocsana Tonis (Bucea-Manea) ${ }^{2}$ \\ 1,2 Spiru Haret University, LuiseMladen@hotmail.com, rocsanamanea.mk@spiruharet.ro
}

\begin{abstract}
Human resource is the most important and valuable asset for a company and investing in training and education should be a priority for organizations and universities. As the investments to bring benefits for economy, the communication and collaboration between organizations (market) and universities (school) must be very close. As a consequence, the aim of the paper was to identify the necessary measures to improve the existing university curriculum by linking it with the labor market requirements. In this regard it was implemented a market research within "Adapt2jobs" POSDRU project, in 2 steps: a survey for organizations and a survey for students. The article presents the results of a quantitative analysis regarding the market demand, the requirements of organizations for employees.
\end{abstract}

Keywords: market research, market requirements on human resources, university curriculum

JEL Codes: 123,129

\section{Literature Review:}

Romania is facing a long-term crisis of employment (decreased with almost 2.2 million people), due to the economic decline and unsustainable economic growth. The employees experience a lack of labour safety. The labour market is faced with rigidities and bottlenecks determined by demographic, educational, professional and social factors. The salary, the main tool of balancing the labor market, has largely lost its economic functions, turning into means of social protection [Nen, 2015].

The current economic context brings new challenges regarding changing organizational paradigms (from mass production to diverse and customized production), market paradigm (the online market extends faster and faster, increasing the competition, the market becoming global) and work paradigm (innovative, diverse and flexible working methods and skills, flexible working hours, changing the work place in time, working online) [Achim, 2015].

The work paradigm is well described by a quantitative research focused on the impact of organizational climate on employees work style in Romanian public sector. The study reveals the organizational support and training is an incentive and encouraging frame for creative attitudes in the workplace. Efficient management has a positive impact on employees' work style. Furthermore while 


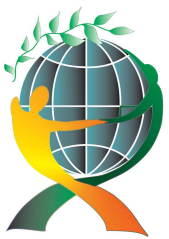

\author{
(online) $=$ ISSN $2285-3642$ \\ ISSN-L = $2285-3642$ \\ Journal of Economic Development, Environment and People \\ Volume 5, Issue 3, 2016 \\ URL: http://jedep.spiruharet.ro \\ e-mail: office jedep@spiruharet.ro
}

struggling with the large number of tasks to be met, the employees cannot successfully practice and develop their management skills. The level of positive motivation in the organizational climate makes the employees to be more involved in their wok activity. The study emphasizes the importance of long-term positive interpersonal relationships in the workspace [Niculita, 2015].

The dictum TIME IS MONEY (characteristic of capitalist society) and KWOLEDGE IS POWER (characteristic of informational society) is replaced by INNOVATION IS THE PRESENT AND THE FUTURE as a characteristic of green sustainable society.

New economy in all its manifestations, changes the requirements regarding knowledge acquired because $80 \%$ exiting technology will be replaced in the next decade and the average life skills of an employee is $3-5$ years [Troia, 2011].

The literature review underline that continuous training of employee is essential, because there is a gap between knowledge acquired in schools and the skills, professional aptitudes and knowledge requested by employers. One reason of this gap is the trend of evolution of some type of activities, such as IT, accountability, online-marketing (3-6 mounts) and the impossibility of university to keep up with this trend. The article's scope is to find out a solution for this problem.

As the demand for labour is restricted, the pressure increases on the educational system in general, and on higher education, in particular [Nen, 2015].

Most of universities try to cope with this gap and pressure accessing European funs in order to increase investments on education and to adapt to market. Thus Da Vinci programs enhanced skills and competences of students and facilitated their integration into the labour market, Erasmus Programmes assumed mobility activities of students and teachers, improving the transparency and recognition of qualifications and Grundtvig facilitated transnational cooperation and collaboration between the various bodies which promote adult education.

In this context the public expenditure on education as a percentage of GDP is presented in figure 1 . It is easy to observe that Malta, Portugal, Switzerland and northern countries, such as Denmark, Finland, Sweden spend almost double then the sum spent by Romania and Germany. They are followed by Cyprus, UK, Hungary and Norway. The expenditure with education is reflected in a higher standard of living, as observed in northern countries.

The participation rate in education and training (last 4 weeks) by sex and age ( 25 to 64 years) is also two times higher in Nordic countries in comparison with European Union 28 media, ever 3 times higher in Denmark, Sweden, Switzerland (Fig.2). This rate is the smallest for Romania; it is five times smaller than the EU average. It reflects a very low living standard, too expensive studies and most of all the lack of good models and low level of awareness regarding the real value of knowledge. An interesting situation is happening in Portugal, where government expenditure in education is very high, but the participation rate in education is lower than the EU average. It is probably a low degree of awareness regarding these investments and the education facilities.

The literature review emphasizes the importance of lifelong learning programs, respecting recommendations 93/404/EEC [Dumitrescu, 2015]. The organizations are not prepared to invest in staff training. 


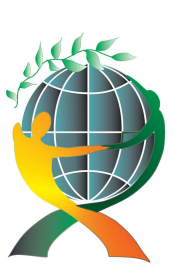

$$
\begin{gathered}
\text { (online) }=\text { ISSN } 2285-3642 \\
\text { ISSN-L = 2285 - } 3642
\end{gathered}
$$

Journal of Economic Development, Environment and People

Volume 5, Issue 2, 2016

URL: http://jedep.spiruharet.ro

e-mail: office jedep@spiruharet.ro

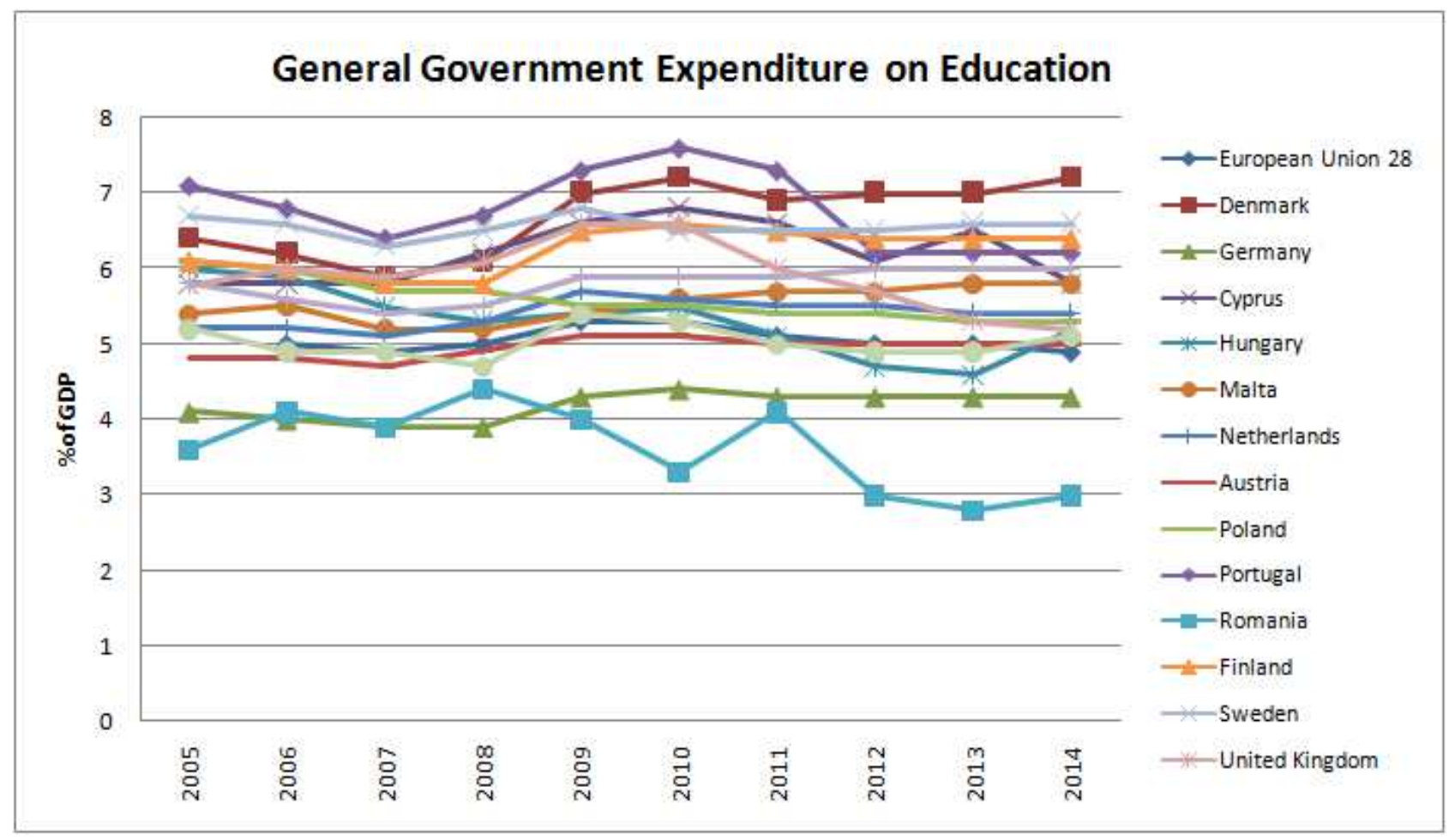

Fig.1: General Government Expenditure on Education, total (\%GDP) Source: Eurostat, own prelucration

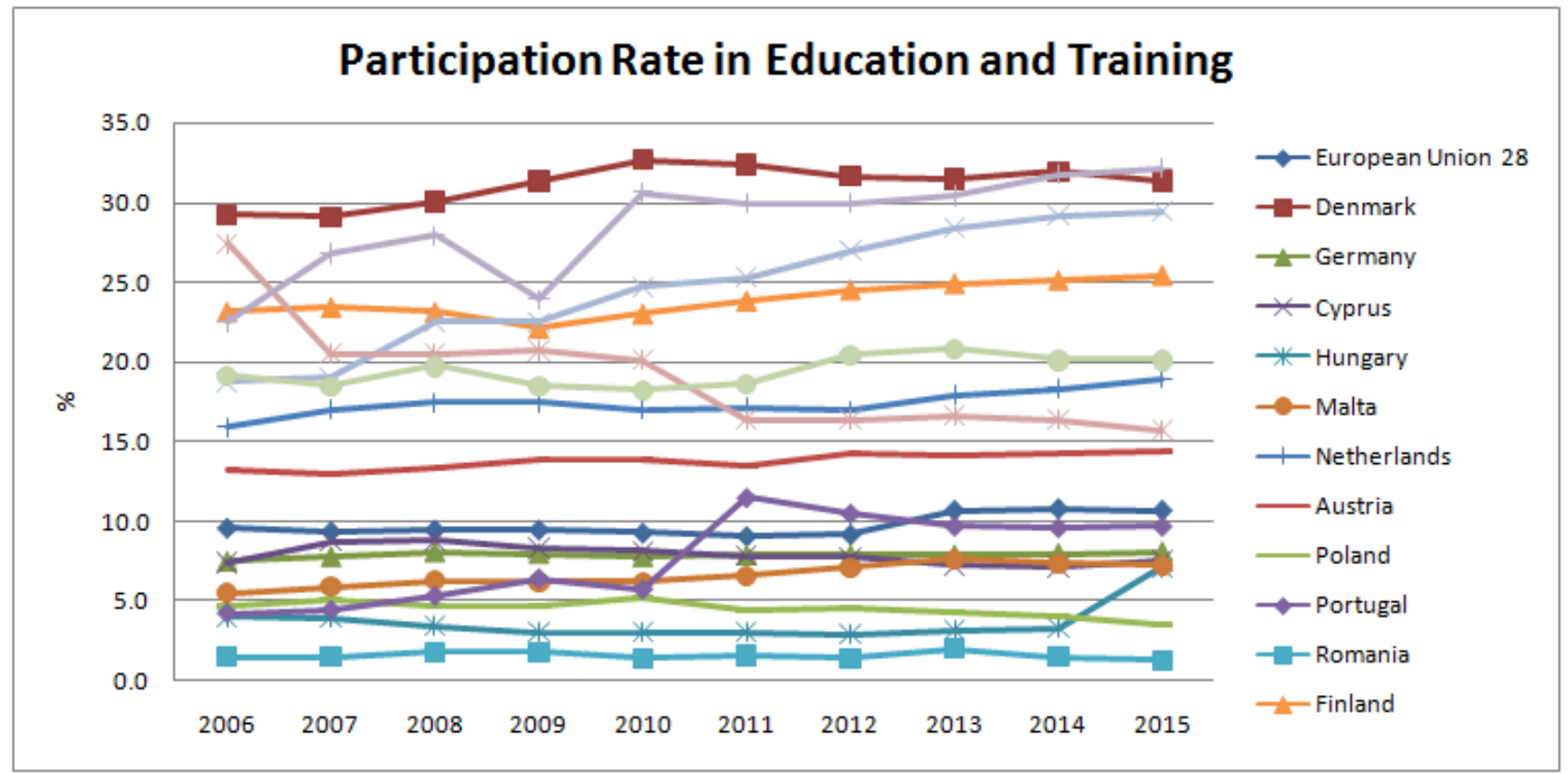

Fig.2: The Participation Rate in Education and Training rises, Source: Eurostat, own prelucration 


\author{
(online) $=$ ISSN $2285-3642$ \\ ISSN-L = $2285-3642$ \\ Journal of Economic Development, Environment and People \\ Volume 5, Issue 3, 2016 \\ URL: http://jedep.spiruharet.ro \\ e-mail: office jedep@spiruharet.ro
}

\title{
2. Research Methodology
}

Within the project was initiated a cross-examination based on a questionnaire survey among both employers in the first stage and among students, in the second stage. We have chosen the questionnaire because it is "a scientific method of investigation, often the only available, of the social life subjective universe - opinions, attitudes, beliefs, knowledge, interests, etc. in a individually and collectively manner "[Zamfir, Vlăsceanu, 1993]. The results that we have obtained from the processing of information collected via questionnaire are essential for adapting curriculum and educational package to labor market requirements.

During the study were applied 20 questionnaires to employers from different fields of activity, most of it being privately owned (approx. 80\%). Most of them are SMEs. The questionnaire has 4 sections: organization profile, staff recruitment, professional skills and performances and the characteristics of the desirable employee.

The results of the questionnaire for employers

\subsection{Section A. Organization Profile}

Employers who participated in the survey work in areas such as Financial intermediation, Insurance and pension funding, Legal, accounting and auditing, tax consulting, Real Estate, Research and Development, Transport, Hotels and restaurants. $83.3 \%$ of investigated organizations are privately owned and $16.7 \%$ in public ownership.

In terms of organization size, most are micro-enterprises that have less than 10 employees (33.3\%), and small size enterprises (with between 10 and 49 employees $-27.8 \%$ ) and average 50-249 (27.8\%) and the fewest are large enterprises with 250 employees or more (11.1\%).

An important element is the age of the organization. It had been chosen enterprises that proved experience on the market. $38.9 \%$ of organizations included in the survey are older than 10 years, 33.3\% have between 5 and 10 years of experience and $27.8 \%$ operating in the market have less than five years.

\subsection{Section B. Staff Recruitment}

A proportion of $16.7 \%$ of employers stated that they had vacancies for seeking employees for more than three months.

When asked about any difficulties encountered in the recruitment of university graduates in the field of Economics, only $5.6 \%$ of employers say that they are encountering such difficulties.

Among the methods utilized mainly for recruitment, employers have identified the following: the use of its database $(60 \%)$ through portals work online $(55 \%)$, recommendations acquaintances $(45 \%)$ by the NEA (40\%), ads newspapers (40\%), attending job fairs (35\%). Recruitment methods less used were: collaboration with public and private universities (15\%) or through private placement agencies (10\%).

Most of employers offer good working conditions to entice graduates to engage, $(60 \%)$ or the possibility of promoting (60\%). They also offer the opportunity to participate in ambitious projects (50\%). $45 \%$ of employers consider that the existence of the organization concern regarding the culture of excellence is able to stimulate young graduates to engage. Fewer employers offer a great salary (35\%) or a flexible work schedule (30\%). 


\author{
(online) $=$ ISSN $2285-3642$ \\ ISSN-L = $2285-3642$ \\ Journal of Economic Development, Environment and People \\ Volume 5, Issue 2, 2016 \\ URL: http://jedep.spiruharet.ro \\ e-mail: office jedep@spiruharet.ro
}

All employers have hired investigated in the past five years economic science graduates.

\title{
2.3. Section C. Professional Skills and Performances
}

The questions in this section focused on the ability of education to support the development of academic skills and competences needed by graduates of the economic sciences.

The employers were asked to what extent are satisfied with the training of university graduates economic sciences. $56.3 \%$ of employers say they are largely satisfied and $43.8 \%$ are neither satisfied nor dissatisfied.

Regarding the correlation between the knowledge and skills acquired by graduates of economic sciences and job requirements, only $43.8 \%$ of employers believe that they largely correspond. The other employers say that the skills and knowledge gained are in accordance with job requirements only in small or very small amount $(18.8 \%)$ or so and so $(37.5 \%)$. Recorded average score is 3.19.

If in terms of theoretical knowledge acquired by graduate employers were largely satisfied to $43.8 \%$, things are totally different when it comes to practical knowledge where the figure is only $6.3 \%$. So a big minus the Romanian university system is that it puts a heavy emphasis on theoretical knowledge while practical training is neglected.

$37.5 \%$ of respondents admitted that university graduates in the country are only slightly able to adapt quickly to changes in the field for which they had been trained, while $18.8 \%$ of employers believe that graduates will face largely.

The percentage of those who say that university graduates are able only to a limited extent to use the acquired knowledge for faster adaptation to job requirements is $25 \%$, while the proportion of those of the opposite view is $18.8 \%$.

Regarding the skills that university graduates own when hiring their average scores were recorded in the table 1 (where 1 - very poor, 5 - very good).

Thus, university graduates are the highest rated in terms of the ability to use the computer and surf the internet (average score 4.50) and the ability to inform and communicate in foreign languages (3.50), and ranked poorly in terms of ability to coordinate activities (2.75) or working under stress (2.75).

An overwhelming proportion of employers (81.3\%) state that their employees graduate of economic sciences requires the development of skills through further training. However only $25 \%$ of respondents said that the organization had funded in the past two years additional training activities for their employees, in order to better adapt to the demands of the workplace. 


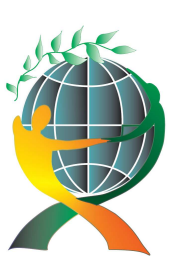

\author{
(online) $=$ ISSN $2285-3642$ \\ ISSN-L = $2285-3642$ \\ Journal of Economic Development, Environment and People \\ Volume 5, Issue 3, 2016
}

URL: http://jedep.spiruharet.ro

e-mail: office jedep@spiruharet.ro

Table 1: The skills that university graduates own

\begin{tabular}{|c|l|c|}
\hline No & \multicolumn{1}{|c|}{ Type of proficiency } & $\begin{array}{c}\text { Average } \\
\text { score }\end{array}$ \\
\hline 1 & ability to use the computer and surf the internet & 4,50 \\
\hline 2 & $\begin{array}{l}\text { ability to inform and communicate in foreign } \\
\text { languages }\end{array}$ & 3,50 \\
\hline 3 & $\begin{array}{l}\text { social skills and the ability to build a professional } \\
\text { networking }\end{array}$ & 3,44 \\
\hline 4 & analysis and synthesis capacity & 3,38 \\
\hline 5 & ability to assume responsibilities & 3,25 \\
\hline 6 & oral and written communication skills & 3,25 \\
\hline 7 & teamwork ability & 3,25 \\
\hline 8 & ability to quickly assimilate new knowledge & 3,25 \\
\hline 9 & Spirit of initiative & 3,19 \\
\hline 10 & creativity and ability to solve problems & 3,06 \\
\hline 11 & ability to express and argue their opinions & 3,00 \\
\hline 12 & negotiating skills & 3,00 \\
\hline 13 & ability to effectively manage time and resources & 3,00 \\
\hline 14 & ability to coordinate activities & 2,75 \\
\hline 15 & ability to work under stress & 2,75 \\
\hline
\end{tabular}

\title{
2.4. Section D. Characteristics of the desirable employee
}

This section had the aim to identify the desirable characteristics of employee by the employer. The features list was designed in accordance with recruiters' presentations and brainstorming session about the ideal candidate. The brainstorming session took place at the Conference of Adapt2jobs Project launching, from 26 to 17 June 2014. Employers were asked to list and prioritize the five main transversal competences and five specific skills of economic sciences graduates should possess in order to succeed in the organization they represent.

Transversal skills which most employers as the most important were: the ability of teamwork (12 responses), communication skills oral and written (9 responses), the ability to assume responsibilities (6 responses), capacity to expose and argue opinions (5 responses), spirit of initiative (4 responses), the ability to inform and communicate in foreign languages (4 responses), the ability to use the computer and surf the internet ( 3 answers), creativity and ability to solve problems ( 3 replies) negotiating skills ( 3 replies) skills, socialization and building a professional networking ( 2 answers) and the ability to quickly assimilate new knowledge (2 responses) . 


\author{
(online) $=$ ISSN $2285-3642$ \\ ISSN-L = $2285-3642$ \\ Journal of Economic Development, Environment and People \\ Volume 5, Issue 2, 2016 \\ URL: http://jedep.spiruharet.ro \\ e-mail: office jedep@spiruharet.ro
}

In the same time specific skills which most employers states to be the most important were: the execution of professional tasks in complex conditions of autonomy and professional independence (13 responses), decisions according to values and ethical principles (13 responses) and taking role (eg. in a team) to run activities (11 responses).

Most employers find that most of their employees should have higher education (64.3\%).

In the process of graduates recruitment, the employers interviewed consider that the most important aspects are the qualifications of the candidate ( $65 \%$ of respondents said so), a very good academic background $(55 \%)$, work experience $(50 \%)$, reputation of the institution graduated $(40 \%)$, and the age (35\%). The employers considered less important 2 features: specializations in the field (10\%) and participation in volunteering $(10 \%)$.

\title{
3. Conclusions
}

Thus we conclude that:

- knowledge and skills acquired by graduates of economic sciences in many cases do not match the job requirements;

- vast majority of employers believe that graduates do not possess sufficient practical knowledge and that's a big minus is that the Romanian university system places a heavy emphasis on theoretical knowledge while practical training is neglected;

- a high proportion of employers opinion that university graduates in the country are only slightly able to adapt quickly to changes in the field graduated;

- university graduates are the highest rated in terms of the ability to use the computer and surf the internet and the ability to inform and communicate in foreign languages, while being the underdog in terms of capacity to coordinate activities or to work under pressure;

- overwhelming proportion of employers believe that their employees graduate field of economic sciences requires skills development through additional training, however only a quarter of the organizations financed in the past two years activities additional training for employees to better adapt to the demands of the employers;

- transversal skills which most employers as the most important employee desirable were: the ability of teamwork, communication skills oral and written, ability to take responsibility, and the ability to express and argue their views;

- specific skills which most employers consider that are the most important were: the execution of professional tasks in complex conditions of autonomy and professional independence, making decisions according to values and ethical principles and assumption of roles within a team to conduct activities .

These are issues which will have to take into account when we plan review of the educational package for economic sciences. 


\author{
(online) $=$ ISSN $2285-3642$ \\ ISSN-L = $2285-3642$ \\ Journal of Economic Development, Environment and People \\ Volume 5, Issue 3, 2016 \\ URL: http://jedep.spiruharet.ro \\ e-mail: office jedep@spiruharet.ro
}

\title{
4. Further research
}

In a future article the author will be able to present the economic studies graduates opinion. They expressed their opinion within a survey.

\section{Acknowledgements}

The findings presented in this paper are results of the project Adapt2jobs (The adaptation of the curriculum and the educational package to the labour-market requirements, POSDRU/156/1.2/G/141179), project co-financed from the European Social Fund through the Human Resources Development Sectorial Operational Programme.

\section{References}

[1] M. Nen, Professional Insertion of Highly Qualified Human Resources. Case Study - Romania, Procedia - Social and Behavioral Sciences, Volume 191, 2 June 2015, pp. 1891-1896.

[2] M.-V. Achim, The New Economy-asking for New Education Approaches. Evidence for Romania and other Postcommunist European Countries, Procedia Economics and Finance, Volume 32, 2015, pp. 1199-1208.

[3] Z. Niculita,The Relationship Between Work Style and Organizational Climate for Romanian Employees, Procedia Economics and Finance, Volume 32, 2015, pp. 1042-1049

[4] A. Toia. The technologic progress and the future of work, Market Watch Revenue, June 2011.

[5] M. Dimitrescu, L. V. Sârbu, Y. Lacroix. European Trends for Adults Education in Lifelong Learning Strategy: Modern Methods and Romanian Skills in Training Management, Procedia - Social and Behavioral Sciences, Volume 180, 5 May 2015, pp. 1161-1169.

[6] Zamfir, Vlăsceanu (coord).(1993). Dicţionar de sociologie, Editura Babel, Bucureşti,1993. 